\title{
DOMESTIC WASTEWATER TREATMENT MINIPLAN OF INSTITUTION USING A COMBINATION OF “CONETRAY CASCADE AERATOR" TECHNOLOGY AND BIOFILTER
}

\author{
Naniek Ratni Juliardi A.R*, Rudy Laksmono, Firra Rosariawari, Erwin Chandra \\ Environmental Engineering Department-University of Pembangunan Nasional "Veteran" Jawa Timur \\ Surabaya, East Java, Indonesia \\ E-mail: naniktlupn@yahoo.com
}

ABSTRACT

In Indonesia, the contamination from domestic wastewater is becoming the greatest pollutant and reaches up to $85 \%$ that goes into the body of water. This might worsen the river water quality. To anticipate this condition, there should be some way out, by making use of wastewater as a source of energy. One of those systems is by employing Cone-tray Cascade Aerator combined with Biofilter by using Hydrilla plant which can be used as an alternative of waste water treatment for both domestic and institutional scale. This research was aimed at determining the system capability of aeration combined with biofilter by using hydrilla plant to reduce or eliminate the pollutant load of BOD, COD, and TSS. This research was conducted in a continuous stream of water at $200 \mathrm{~L} /$ hour. The result showed that the best system of Conetray Cascade Aerator combined with biofilter could reduce BOD as much as 69,11\%, COD at 61,14\%, and TSS at $65,45 \%$.

Keywords: Domestic Wastewater, Aeration, Conetray Cascade Aerator, Biofilter, Hydrilla.

\section{INTRODUCTION}

Water is one of the main components to support the life of all living things. For human beings, water is one of the basic needs because they always need and use water. Therefore, the more population of the people the more water required. This fact makes the increase of pollution and the decrease of water quality due to the increase of the people's activity that might cause the danger of life's continuance of many kinds of aquatic biota. This might endanger human being's life. One method that might increase the water quality is by increasing the oxygen content in the water. Conetray Cascade Aerator is one instrument which is capable of dissolving oxygen into the water through air contact gravitationally by means of some steps.

Conetray Cascade Aerator is one type of gravity aerator, a kind of aeration that the way it works is based upon gravitation power. Meanwhile, the water that will be aerated will flow gravitationally due to the different height from one step to another. In every step in the water, it will occur some contact between BOD, COD, and TSS with oxygen so that there will occur oxidation reaction. The more steps the more perfect the oxidation reaction will be. Basically, the aerator consists of 4-6 steps, where every step has its height of $30 \mathrm{~cm}$ with its capacity about 0,01 $\mathrm{m} 3 /$ second per $\mathrm{m} 2$ to relieve rotation (turbulence) in order to increase the aeration efficiency. However, some hindrance often occurs on the edge of the instrument in every step. Moreover, the advantage of employing Conetray Cascade Aerator is that it does not need any treatment. Meanwhile, the weakness/disadvantage is that it needs a larger place to put on. Some factors that affect the process of Conetray Cascade Aerator are the height and the number of Cascade, the width of container and number of plants (Benefield, 1990).

According to the research of Hartini E (2012), the use of one side of the cascade aerator can reduce $98.74 \% \mathrm{Mn}$, and the use of bubble aerator can reduce $76.47 \%$ Mn. COD parameter can also be lowered combination of aeration processes, adsorption, and filtration with a flow rate of $228.33 \mathrm{ml} / \mathrm{min}$, the initial results of $323.55 \mathrm{mg} / \mathrm{lt}$ to $58.95 \mathrm{mg} / \mathrm{lt}$ (Endahwati L. and Suprihatin, 2013)

Some results of domestic wastewater treatment with aeration and the addition of pseudomonas putida bacteria produce an $89.19 \%$ reduction in BOD with oxygen of 2 liters $/ \mathrm{min}$, time of 216 hours, and 10 cells $/ \mathrm{ml}$ (Wibowo ME and Sajidan W, 2006). The process of oxidation pond aeration system - constructed wetland can also reduce COD (Xiaoou Wang et al, 2015).

Fate of the low arsenic concentrations during fullscale aeration and rapid filtration (JCJ Gude et al, 2015). According to John Colt and Eric Kroeger (2013), in general, the aeration process can also improve water quality. Moreover, when combined with vegetation treatment (Phragmites australis) in the scale of wetland, it can reduce COD (Henric Svensson et al, 2015). Also, Enrique J. La Motta( 1996) said a pilot scale tray tower was built at The University of New Orleans urban waste management and research center to study the factors affecting carbon dioxide removal by plain aeration.

A feasibility study of iron-mediated aeration (IMA) was conducted by Yang Deng et al (2013) for treatment of secondary effluent, natural surface water, and simulated contaminated water, which achieved the following removal efficiencies: $82.2 \%$ of glyoxylic acid, $100 \%$ formaldehyde as an oxidation product of glyoxylic acid, $94 \%$ of $\mathrm{Ca} 2 \mathrm{p}$ and associated alkalinity, and $44 \%$ of chemical oxygen demand (COD).

According to Senlin Shao et al (2015), long sludge retention time (SRT) and continuous aeration are generally adopted in powdered activated carbon membrane bioreactor (PAC-MBR) process for micropolluted surface water treatment. The results showed that the intermittent aeration with proper aeration intervals barely reduced the removal efficiency of pollutants, due to the low DO consumption in the bioreactor and the low settling velocity of the sludge (mostly at the range of 0.04 $0.08 \mathrm{~m} \mathrm{~min}^{-1}$ ). 


\section{Domestic Waste Water}

Originally, waste is classified into 3 (three) kinds: agricultural, industrial, and domestic waste. Agricultural waste is originated from pesticide or insecticide use. Plant waste, or more often is called industrial waste, is the waste resulted from the production process. Meanwhile domestic waste or it is often called household waste is the waste from households (Kusno P H,1986).

\section{Working Principle of Conetray Cascade Aerator}

Aeration is another term of gas transfer which is more specialized on the gas transfer of oxygen or process of oxygen addition into the water. Meanwhile, the success of an aeration process depends much on the temperature, oxygen saturation, and the characteristics and turbulence of the water. Meanwhile, the main function of aeration in water treatment is to dissolve the oxygen into the water to increase the content of dissolved oxygen in the water. Moreover, the suspended mixture of active sludge in bioreactor releases the content of dissolved gasses in the water and helps in water stirring. In an aeration process, there are some factors affecting the oxygen transfer, such as Temperature, Oxygen Saturation, Characteristics of Water, and Water Turbulence.

Moreover, in aeration process of conetray cascade aerator, the domestic waste water of institution is collected in one tank or container then let flowed through each of the 5 (five) traps. The water that has passed by each trap will pass through the bio-filter process available in hydrilla plant that has already been determined its number and weight. The water flowed will go to the installation provided for filtration (Benefield, 1990).

\section{METHODOLOGY}

Materials and Tools / Instruments

The materials used in this research covered:

- Domestic waste water of institution

- Hydrilla

Meanwhile, the tools required were:

- Conetray Cascade Aerator

- Valve

- Pump

- Container / Water Reservoir

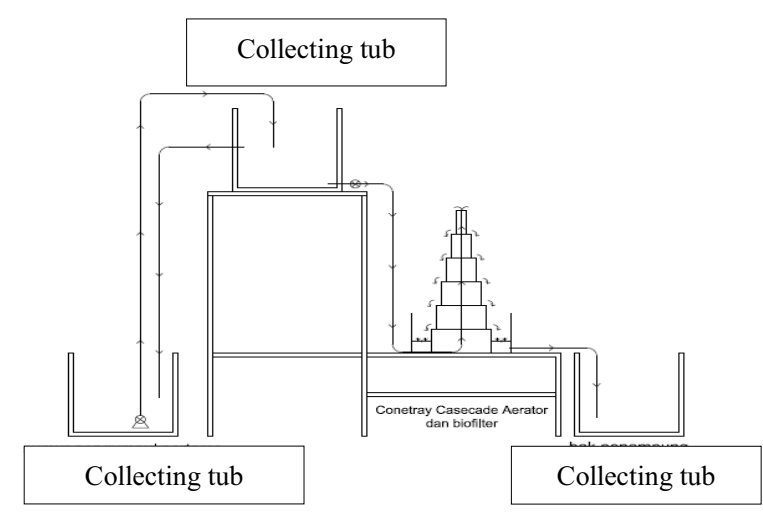

Figure-1. Tool/Instruments.

Variable

The variable used in this research was established variables and treatment variables.

a. The variables established were:

- Rate of flow/discharge of waste water in the container of 200 liters/hour $=0.0033 \mathrm{~m}^{3} /$ Minute

- The diameter of basin/container is $0.5 \mathrm{~m}$
- The number of Cascade: 5 traps

- The Weight of Hydrilla

b. Treatment Variables

- Total number of Plants: 0, 5, 10, 15, 20

- Sampling Time: 5 minutes, 10 minutes, 15 minutes, 20 minutes, 25 minutes

\section{Working Procedure}

Domestic wastewater of institution available in the first water reservoir was pumped into the second reservoir then it was brought down by gravity by controlling the rate of flow from the faucets. The waste water will be picked up to the highest cascade, then it will drop by gravity to pass through each of trap or cascade. After passing through all cascades, the water would touch the hydrilla plant reaching to bio-filtration. Then water would come to the outlet to be collected in one reservoir. The analysis in this research was aimed at knowing the effectiveness of parameter decrease of BOD, COD and TSS in the domestic wastewater of institution by employing Conetray Cascade Aerator combined with biofilter by using Hydrilla.

\section{RESULTS AND DISCUSSION}

The variable employed in this research was dealing with the number of plants and single living/growing time. In 'without plant' process, it was required 5 plants of hydrilla, 10 plants of hydrilla, 15 plants of hydrilla, and 20 plants of hydrilla with some variations of living time: 5 minutes, 10 minutes, 15 minutes, 20 minutes, and 25 minutes.

Initial Characteristics of Domestic Wastewater.

The initial condition of domestic wastewater used in Conetray Cascade Aerator process was combined with the biofilter that had a meaning that the analysis was conducted before the process was begun. This was meant to obtain some initial characteristics description of the material to be processed in Conetray Cascade Aerator which would be combined with a biofilter. The analysis result of initial characteristics could be seen in table 1 below.

Table-1. Initial Characteristics of Domestic Wastewater of Institution.

\begin{tabular}{|l|c|c|c|}
\hline \multirow{2}{*}{ Number } & \multicolumn{3}{|c|}{ Analysis Result } \\
\cline { 2 - 4 } & $\begin{array}{c}\text { COD } \\
\mathbf{m g} / \mathbf{L}\end{array}$ & $\begin{array}{c}\text { TSS } \\
\mathbf{m g} / \mathbf{L}\end{array}$ & BOD mg/L \\
\hline 1 & 176 & 440 & 137 \\
\hline 2 & 376 & 468 & 342 \\
\hline 3 & 324 & 313 & 267 \\
\hline
\end{tabular}

(Sources: Analysis Result of Laboratory, 2015)

Table 1 above showed that BOD, COD, and TSS had not been appropriate with the criteria of quality standards of domestic wastewater (East Java Governor's Regulation No.72, 2013).

In this research, the variable employed was ratio number of plants and time controlling. Some processes are without any plants, 5 plants of Hydrilla, 10 plants, 15 plants, and 20 plants with time variations of 5 minutes, 10 minutes, 15 minutes, 20 minutes and 25 minutes. The domestic wastewater that the institution used in Conetray Cascade Aerator process at the initial condition had the meaning that the analysis was conducted before the process was 
started in order to produce the initial description of material characteristics to be processed in Conetray Cascade Aerator. Based on table 1 above, it could be seen that the ratio of COD, BOD and TSS was still appropriate with the criteria from the quality standard of domestic waste water (the decision of State Minister of Environment, no. 112, 2003).

Having some test of oxygen transfer or aeration been conducted by employing Conetray Cascade Aerator tool combined with biofilter using hydrilla plants, it could be seen that the result of aeration showed there was some fluctuation in the decrease of BOD, COD, TSS in domestic wastewater.

\section{The Effect of Hydrilla Quantity and Living Time in BOD Elimination.}

Variable Variation of Hydrilla Quantity and Living Time could be seen in Table 2 below:

Table-2. Elimination Percentage of BOD

\begin{tabular}{|c|c|c|c|c|c|}
\hline \multirow{2}{*}{$\begin{array}{l}\text { Time } \\
\text { (minute } \\
\text { ) }\end{array}$} & \multicolumn{6}{|c|}{ Elimination Percentage of BOD (\%) } \\
\cline { 2 - 6 } & $\begin{array}{c}\text { Without } \\
\text { Hydrilla }\end{array}$ & $\begin{array}{c}5 \\
\text { Hydrillas }\end{array}$ & $\begin{array}{c}10 \\
\text { Hydrillas }\end{array}$ & $\begin{array}{c}15 \\
\text { Hydrillas }\end{array}$ & $\begin{array}{c}20 \\
\text { Hydrilas }\end{array}$ \\
\hline 5 & 25,32 & 51,16 & 2,92 & 28,36 & 11,98 \\
\hline 10 & 37,88 & 54,96 & 13,45 & 40,64 & 24,71 \\
\hline 15 & 44,31 & 57,08 & 14,32 & 47,07 & 33,33 \\
\hline 20 & 47,37 & 58,68 & 26,61 & 56,43 & 42,69 \\
\hline 25 & 47,51 & 66,21 & 40,64 & 69,11 & 67,41 \\
\hline
\end{tabular}

(Sources: Analysis Result of Laboratory)

Based on Table 2 on 'The Effect of Hydrilla Quantity and Living Time in BOD Elimination', it could be described in the following chart/graph:

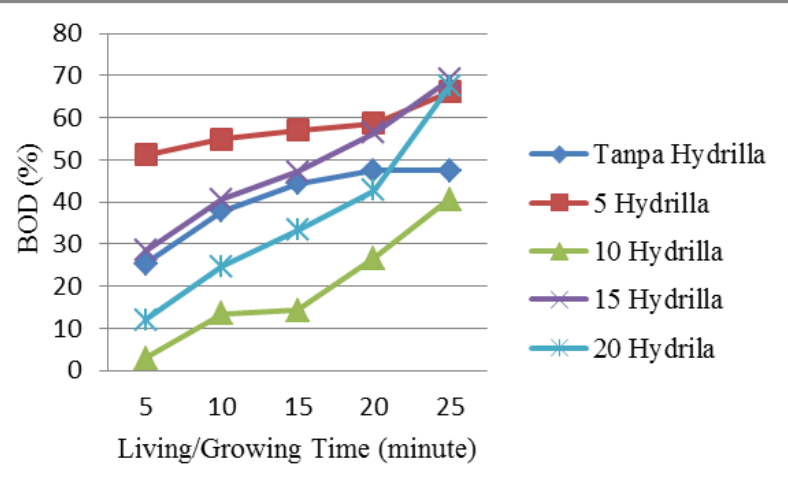

Figure-2. The Relationship between Elimination of BOD (\%), Living/Growing Time (minute) and the Number of Hydrilla.

The parameter used in figure- 2 was a process of conetray cascade aerator combined with a biofilter. Based on our observation, this is the best score of BOD. In accordance with the effect of hydrilla quantity to the decrease of BOD, it was found that the best variable was that of employing 20 plants of hydrilla with its living time of 25 minutes which resulted in its $\mathrm{BOD}$ elimination reaching up to $67,41 \%$.

BOD could decrease in accordance with the number of cascade and duration (time length) of aeration process. This was due to the fact that the longer the aeration time required, the more oxygen to be transferred. This might cause the decomposition increase from organism population to grow better. Moreover, Unus Suriawiria (2008) said that biofilter was a group of microbes, like bacteria and fungus, which was capable of decomposing some organic and inorganic substances available in the wastewater by employing some certain plants.

The Effect of Hydrilla Amount and Living/Growing Time to COD Elimination.

Table-3. Elimination Percentage of COD

\begin{tabular}{|c|l|l|l|l|l|}
\hline \multirow{2}{*}{$\begin{array}{l}\text { Time } \\
\text { (minute) }\end{array}$} & \multicolumn{6}{|l|}{ Elimination Percentage of BOD (\%) } \\
\cline { 2 - 6 } & $\begin{array}{c}\text { Without } \\
\text { Hydrilla }\end{array}$ & $\begin{array}{c}5 \\
\text { Hydrillas }\end{array}$ & $\begin{array}{c}10 \\
\text { Hydrillas }\end{array}$ & $\begin{array}{c}15 \\
\text { Hydrillas }\end{array}$ & $\begin{array}{c}20 \\
\text { Hydrilas }\end{array}$ \\
\hline 5 & 21,45 & 43,27 & 4,25 & 30,58 & 12,11 \\
\hline 10 & 34,54 & 47,63 & 6,11 & 36,71 & 14,64 \\
\hline 15 & 38,9 & 52 & 8,24 & 44,94 & 29,29 \\
\hline 20 & 38,9 & 52,27 & 16,48 & 51,06 & 38,85 \\
\hline 25 & 43,27 & 60,72 & 22,61 & 59,31 & 61,14 \\
\hline
\end{tabular}

(Sources: Analysis Result of Laboratory)

Based on Table 3 above, it could be summarized that the Effect of Hydrilla Amount and Living/Growing Time to COD Elimination could be described in the following chart/graph:

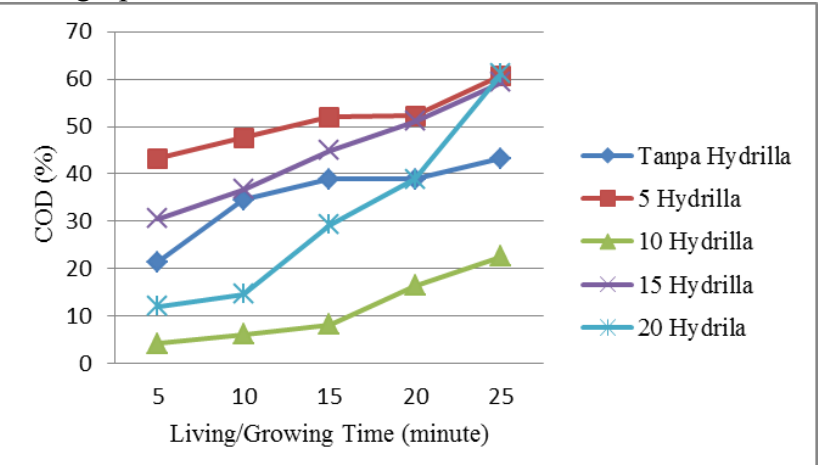

Figure-3. The Relationship between COD Elimination (\%), Living/Growing Time (minute) and the Amount of Hydrilla.

The parameter used in figure- 3 was a process of conetray cascade aerator combined with a biofilter. Based on our observation, this is the best score of COD. In accordance with the effect of hydrilla quantity to the decrease of COD, it was found that the best variable was that of employing 20 plants of hydrilla with its living time of 25 minutes which resulted in its COD elimination reaching up to $61,14 \%$. COD elimination could increase as the other variable (living time) and the amount of plants (cascades) did. Meanwhile, the amount of oxygen required as an aeration effect had been fulfilled to oxidize some organic substances. Moreover, Unussuriawiria (2008) said that biofilter, like BOD, was one of the ways/solutions of disposal processings by employing plants which had some capability (like bacteria and fungus) of decomposing some organic and inorganic substances/compounds.

\section{The Effect of Hydrilla Amount and Living/Growing Time to TSS Elimination}

Table-4. The Effect of Hydrilla Amount and Living/Growing Time to TSS Elimination

\begin{tabular}{|c|c|c|c|c|c|}
\hline \multirow{2}{*}{$\begin{array}{l}\text { Time } \\
\text { (minute) }\end{array}$} & \multicolumn{5}{|c|}{ Elimination Percentage of BOD (\%) } \\
\cline { 2 - 6 } & $\begin{array}{c}\text { Without } \\
\text { Hydrilla }\end{array}$ & $\begin{array}{c}5 \\
\text { Hydrillas }\end{array}$ & $\begin{array}{c}10 \\
\text { Hydrillas }\end{array}$ & $\begin{array}{c}15 \\
\text { Hydrillas }\end{array}$ & $\begin{array}{c}20 \\
\text { Hydrilas }\end{array}$ \\
\hline 5 & 15,22 & 57,72 & 21,36 & 31,41 & 8,22 \\
\hline 10 & 18,18 & 60 & 23,93 & 32,47 & 8,75 \\
\hline 15 & 19,31 & 61,81 & 25,64 & 35,04 & 9 \\
\hline 20 & 19,77 & 64,31 & 28,21 & 36,53 & 9,43 \\
\hline
\end{tabular}




\begin{tabular}{|l|l|l|l|l|l|}
25 & 57,04 & 65,45 & 29,91 & 38,88 & 10,57 \\
\hline
\end{tabular}

(Sources: Result Analysis of Laboratory)

Based on Table 4 above, it could be summarized that the Effect of Hydrilla Amount and Living/Growing Time to TSS Elimination could be described in the following chart/graph:

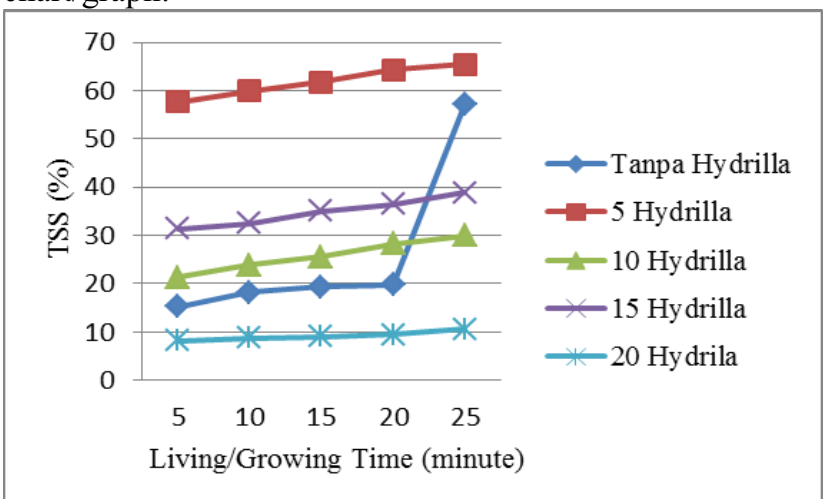

Figure- 4. The Relationship between Elimination of TSS (\%) and Living/Growing Time (minute) to the Amount of Hydrilla.

Figure-4 showed that the best variable was that of employing 5 plants of hydrilla with a living time of 25 minutes for TSS elimination. As Unus Suriawiria (1993) said that a group of microbes, like bacteria and fungus growing/living symbiotically around plants, both plants living in soil and aquatic habitat could grow/live dependently to those plants. These groups of microbes are usually called 'rhizosphere microbes'. Therefore, the higher the number of available plants, the higher the TSS will be.

\section{CONCLUSION}

Referring to the research result and discussion above, it could be concluded as follows: A combination of conetray cascade aerator and a biofilter has been created, where the best system could reduce BOD as much as $69.11 \%$, COD $61.14 \%$, and TSS $65.45 \%$ on debit of 200L/hour.

\section{ACKNOWLEDGMENTS}

Acknowledgments are addressed to the Directorate of Research and Community Service, the Directorate General of Higher Education, Ministry of Education and Culture, that have funded the research in 2015, Seeded research university No. SPP/002/Lit/ LPPM/II/2015.

\section{REFERENCES}

Benefield, Larry D. 1990. "Process Chemistry For Water and Wastewater Treatment", Prentice Hall Inc., New Jersey.

Enrique J. La Motta et al. 1996. Corrosion Control of drinking water Using Tray Aerator, Jurnal Environmental Engineering, 122: 640-648.

East Java Governor's Regulation No.72, 2013.

Endahwati L dan Suprihatin. 2013. A combination of aeration processes, adsorption and filtration in wastewater treatment fishery, the scientific journal Environmental Engineering Vol 1 No 2.

Hartini E. And Sajidan W.2012. Effectiveness and Bubble Aerator Cascade aerator in lowering levels of Manganese Water Well Drilling, Journal of Public Health, Pack 8 (1): 44-52.

Henric Svensson, B€orje Ekstam, Marcia Marques, William Hogland. 2015. Removal Of Organic

Pollutants from oak leachate in pilot-scale wetland systems

: How efficient are aeration and vegetation treatments?, Water Research 84: 120-125.

John Colt and Eric Kroeger. 2013. Impact aeration and alkalinity on the water quality and product quality of transported tilapia - A simulation Study, Aquacultural Engineering 55: 46-58.

J.C.J.Gude, Rietveld, L.C., van Halem, D. 2015. Fate of low arsenic concentrations during full-scale aeration and rapid filtration, Water Research,doi 10.1016/j, watres 2015.10.034.

Kusno P H.1986.Environmental Health, Public Health Faculty, University of Indonesia.

Muhammad Eko Wibowo Romayannto et al. 2006. Domestic waste water treatment with aeration and addition of Pseudomonas putida, Bioteknologi 3 (2) :4249.

Metcalf and Eddy. 2003. "Wastewater Engineering Treatment and Reuse", $4^{\text {th }}$ Edition, Mc.Graw - Hill Inc., Singapore.

Reynolds T.D. and Richards P.A., 1996. "Unit Operations and Processes in Environmental Engineering", $2^{\text {nd }}$ Edition, Boston, PWS: Publishing Company.

Sadatomi Michio. 2011. "Micro Bubble Generation Rate and Bubble Dissolution Rate into Water by a Simple Multi Fluid Mixer with Orifice and Porous Tube", Graduate School of Science and Technology, Kumamoto University. Japan.

Said N.I. 2005. "The removal method of Iron and Manganese in Drinking Water In Domestic",Water Journal Indonesia (JAI), 1(5): 239-250.

Sutrisno. 1982. “”Water Supply Technology, BinaAksara. Jakarta.

Suriawira Unus. 2008. "Microbiology water and the foundations of processing emissions are biologically”,Alumni, Bandung.

Suriawiria Unus. 1993. Water Microbiology, first printing , second edition, ITB, Bandung.

Senlin Shao, Fangshu Qu, Heng Liang*, Kai Li, Huarong Yu, Haiqing Chang, Guibai Li.2015. Powdered activated carbon - membrane bioreactor operated under 
intermittent aeration and short sludge retention times for micro-polluted surface water treatment, International Biodeterioration \& Biodegradation 102:81-88.

The Decision of State Minister of Environment no. 112, 2003.

Xiaoou Wang, Yimei Tian, Xinhua Zhao, Sen Peng, Qing Wu, Lijian Yan. 2015. Effects of aeration position on organics, nitrogen and phosphorus removal in combined oxidation pond-constructed wetland systems, Bioresource Technology 198: 7-15.

Yang Deng, James D. Englehardt ,Samer Abdul-Aziz, Tristan Bataille,Josenrique Cueto, Omar De Leon, Mary E. Wright, Piero Gardinali,Aarthi Narayanan, Jose Polar, Shibata Tomoyuki .2013. Ambient iron-mediated aeration (IMA) for water reuse, Water Research $47: 850$-8 58 . 